\title{
HEAVY METALS IN SOILS AND PLANTS IN MANGO ORCHARDS IN PETROLINA, PERNAMBUCO, BRAZIL ${ }^{(1)}$
}

\author{
João Paulo Siqueira da Silva ${ }^{(2)}$, Clístenes Williams Araújo do Nascimento ${ }^{(3) *}$, Caroline \\ Miranda Biondi ${ }^{(3)}$ \& Karina Patrícia Vieira da Cunha ${ }^{(4)}$
}

\begin{abstract}
SUMMARY
The monitoring of heavy metal concentrations in areas under intensive agriculture is essential for the agricultural sustainability and food safety. This paper evaluates the total contents of heavy metals in soils and mango trees in orchards of different ages $(6,7,8,9,10,11,14,16,17,19$, and 26 years) in Petrolina, Pernambuco, Brazil. Soil samples were taken from the layers 0-20 cm and 20-40 $\mathrm{cm}$, and mango leaves were collected in the growth stage. Areas of native vegetation (Caatinga) adjacent to the cultivated areas were used for comparison. The total concentrations of heavy metals $(\mathrm{Cu}, \mathrm{Cr}, \mathrm{Fe}, \mathrm{Zn}, \mathrm{Mn}, \mathrm{Ni}$, and $\mathrm{Pb}$ ) were determined in soils and leaves. In general, mango cultivation led to $\mathrm{Cu}$ and $\mathrm{Zn}$ accumulation in the soil surface and to a reduction in the contents of $\mathrm{Ni}, \mathrm{Pb}, \mathrm{Mn}$, and $\mathrm{Fe}$ in surface and subsurface. Since contamination by $\mathrm{Cu}, \mathrm{Zn}$, and $\mathrm{Cr}$ was detected, these areas must be monitored to prevent negative environmental impacts. For instance, the presence of $\mathrm{Cr}$ in mango tree leaves indicates the need to investigate the source of the element in these orchards. The management strategies of the different companies led to deficiency or excess of some metals in the evaluated areas. However, the Fe and Mn levels were adequate for the mineral nutrition of mango in all areas.
\end{abstract}

Index terms: Trace elements, agricultural inputs, guiding values, contamination.

(1) Part of Master disssertation of first author to the Federal Rural University of Pernambuco (UFRPE), Recife (PE), Brazil. Received for publication in September, 6, 2011 and approved in June, 13, 2012.

(2) Agronomist, CAPES scholarship, PhD studente in Soil Science/UFRPE, CEP 52171-920, Recife (PE), Brazil. E-mail: jprsp@yahoo.com.br

(3) Professors of the Departament of Agronomy/UFRPE, CEP 52171-920, Recife (PE). E-mail: clistenes@depa.ufrpe.br, carolinebiondi@yahoo.com

(4) Professor of Departament of Civil Engeneering, Center of Tecnology - Federal University of Rio Grande do Norte, CEP 59072970, Natal (RN), Brazil. E-mail: cunhakpv@yahoo.com.br 


\title{
RESUMO: METAIS PESADOS EM SOLOS E PLANTAS EM POMARES DE MANGA, EM PETROLINA, PERNAMBUCO
}

\begin{abstract}
O monitoramento dos teores de metais pesados nas áreas com uso intensivo de insumos agrícolas é de grande importância para a sustentabilidade agrícola e para a segurança alimentar. O objetivo deste trabalho foi avaliar os teores totais de metais pesados em solo e planta em áreas de mangueira com diferentes tempos de cultivo (6, 7, 8, 9, 10, 11, 14, 16, 17, 19 e 26 anos), em Petrolina (PE). Foram coletadas amostras de solo nas profundidades de 0-20 e 20-40 cm e de folhas de mangueira na fase vegetativa. Áreas de vegetação nativa (caatinga), adjacentes às áreas cultivadas, foram utilizadas para comparação. As concentrações totais de metais pesados $(\mathrm{Cu}, \mathrm{Cr}, \mathrm{Fe}, \mathrm{Zn}, \mathrm{Mn}, \mathrm{Ni}$ e $\mathrm{Pb})$ foram determinadas em solos e folhas. $\mathrm{O}$ cultivo de mangueira proporcionou acúmulo superficial dos metais $\mathrm{Cu}$ e $\mathrm{Zn}$ e redução dos teores de $\mathrm{Ni}, \mathrm{Pb}, \mathrm{Mn}$ e $\mathrm{Fe}$, tanto em superfície como em subsuperfície. As áreas cultivadas apresentaram contaminação por $\mathrm{Cu}, \mathrm{Zn}$ e $\mathrm{Cr}$, devendo ser feitos monitoramentos nessas áreas para evitar impactos ambientais. Os diferentes tipos de manejo das empresas no cultivo de manga proporcionaram deficiência e excesso de alguns micronutrientes nas áreas avaliadas. Ferro e Mn, no entanto, supriram a nutrição mineral da mangueira em todas as áreas. A presença de $\mathrm{Cr}$ nas folhas de mangueira sugere a necessidade de investigação da ocorrência desse metal nessas áreas cultivadas.
\end{abstract}

Termos de indexação: Elementos-traço, insumos agrícolas, valores orientadores, contaminação.

\section{INTRODUCTION}

The Brazilian fruit production is nationally and internationally relevant, accounting for around $25 \%$ of the total national agricultural production and of $10 \%$ of the international fruit production, respectively (Lacerda \& Lacerda, 2004; Medeiros et al., 2005). One of the fruits with a high commercial value is mango (Mangifera indica L.) (Albuquerque et al., 1999). In northeastern Brazil, mango is a key element of the regional economy, produced for exportation (Ribeiro et al., 2009), mainly for the European and North American markets (Lucafó \& Boteon, 2001), and recently focused on Asia as well. Approximately $92 \%$ of the country's mango exports are produced in this region (Silva, 2008).

The high mango production of this region, of around $25 \mathrm{t} \mathrm{ha}^{-1}$ (Silva, 2008), is the result of a mechanized agriculture with intensive application of agricultural inputs. However, the increase in the use of fertilizers and pesticides causes a series of environmental impacts, e.g., contamination by heavy metals, salts, and agrotoxics that leach and flow from the cultivated areas into watersheds and groundwater sources (Berti, 2003) and may also accumulate in the soil.

Fertilizers, for example, despite providing crops with nutrients, contain heavy metals that are potentially toxic to human health and to the environment (Peris et al., 2008). These elements also frequently form part of the active components of pesticides. Thus, the continued use of fertilizers and pesticides was identified as the primary pathway for the introduction of metals into agricultural soils (Núñez et al., 2006). Organic fertilizers, depending on the origin, can also release heavy metals in the soil, originating mainly from additives in animal feed (O’Neill, 1993; Mendes et al., 2010).

In the Brazilian literature, data that reflect the changes in the soil chemical properties as related to the time of mango cultivation, mainly focused on the behavior of heavy metals in these soils, are scarce. Therefore, the behavior of these elements in the soilplant system should be evaluated, in order to find solutions or control methods to monitor the accumulation of these metals in soil and plants, reducing the risk of environmental pollution (Oliveira et al., 2008).

In this context, due to the importance of environmental monitoring of crops with a high contribution of agrochemical inputs, as in the case of mango farming in Northeastern Brazil, this study had the objective of evaluating heavy metal contents $(\mathrm{Cu}, \mathrm{Cr}, \mathrm{Fe}, \mathrm{Mn}, \mathrm{Ni}, \mathrm{Pb}$, and $\mathrm{Zn}$ ) of soil and plants in mango orchards after different cultivation periods.

\section{MATERIAL AND METHODS}

The soils and plant samples analyzed were collected from mango orchards in Petrolina, Pernambuco, Brazil (9'23' 38.97" S, $40^{\circ} 30^{\prime} 34.58^{\prime}$ ' W).

The 11 study areas with different histories of fertilization and liming belong to eight agricultural companies producing mainly for mango exportation. In general, fertilizing by agricultural companies provides $40 \mathrm{~L} /$ plant of organic matter $(\mathrm{OM})$ annually from animal sources, such as goat or cattle manure or other, commercial products used as organic 
fertilizers. The companies use different $\mathrm{N}$ doses and sources, the most common of which is ammonium sulfate, at rates of $300-500 \mathrm{~g} / \mathrm{plant}$. The most commonly used $\mathrm{K}$ source was potassium sulfate, at rates of $100-800 \mathrm{~g} / \mathrm{plant}$. For phosphorus, one company reportedly applies $1,000 \mathrm{~g} /$ plant of superphosphate. Some companies utilize other types of fertilizers, such as magnesium sulfate, calcium nitrate, zinc sulfate, iron sulfate, and boric acid, among others. In the different phenological stages of the crop, the highest fertilizer rates are applied during the production period. The acidity in the soil surface and subsurface is reduced, when necessary, by lime and gypsum application. All companies water their crops daily by micro-sprinkler irrigation. To control pests and diseases, all companies adopted the integrated fruit production (IFP) program, with applications of pesticide spraying.

Soil samples were collected from orchards with mango trees of 11 ages $(6,7,8,9,10,11,14,16,17$, 19 , and 26 years since planting) and from their respective reference areas (Caatinga biome with no or minimal human interference). Soil from two layers (0-20 and 20-40 cm) was sampled on the edges of the area under the tree canopy. For this purpose, the areas were divided into three equal plots, covering an area of 1,040 or $1,800 \mathrm{~m}^{2}$, with a tree spacing of $8 \times 5 \mathrm{~m}$ or $10 \times 10 \mathrm{~m}$, respectively. Of each plot, 15 points were randomly sampled to form the composite sample.

To evaluate the contents of heavy metals in the mango plants, four leaves/plant were collected, in the four cardinal directions, at the average canopy height. To collect the samples, the cultivated area was divided into three equal plots. On each plot, 15 trees were randomly selected in the crop rows, at the points of soil sampling, with the exception of the 8-year-old orchard, from which no leaves were collected because, unlike the other areas, the crop was in the production stage Normal mature and recently matured branches were sampled, taking the leaves from the middle section of the penultimate or last offshoot of the branch (Embrapa, 2000).

The soil samples were air-dried, ground and sieved through $2 \mathrm{~mm}$ mesh. To determine the total contents of the metals $\mathrm{Cu}, \mathrm{Cr}, \mathrm{Fe}, \mathrm{Zn}, \mathrm{Mn}, \mathrm{Cd}, \mathrm{Ni}$, and $\mathrm{Pb}$, sub-samples of these soils were ground in an agate mortar and sieved through $0.3 \mathrm{~mm}$ (ABNT no. 50); a stainless steel screen was used to avoid contamination. The soil and plant samples were digested by method 3051A (USEPA, 1998). The metals were determined in an atomic absorption spectrophotometer (AAnalyst 800 Perkin Elmer), using the flame technique.

The analysis quality was controlled by comparison with samples with known metal contents, certified by the NIST (National Institute of Standards and Technology). SRM 2709 San Joaquin soil (Baseline trace element concentrations) and SRM 1570a (Trace elements in spinach leaves) were digested and every 30 samples were analyzed.

The statistical analysis was performed in a $2 \times 2$ factorial arrangement (two environments and two layers) with three replicates, for a total of 132 experimental units. For the chemical analysis of plants, 10 cultivation periods were considered with three replicates, for a total of 30 experimental units. The statistical analysis was based on the application of the $\mathrm{F}$ test to analysis of variance, correlation analysis, and Tukey's Test ( $\mathrm{p}<0.05$ ), using Statistical Analysis System software (SAS, 1999).

\section{RESULTS AND DISCUSSION}

Recoveries (in \%) of the elements expressed in comparison to NIST values were as follows: $\mathrm{Zn}(97 \%)$, $\mathrm{Pb}(101 \%), \mathrm{Fe}(119 \%), \mathrm{Ni}(83 \%), \mathrm{Mn}(103 \%)$, and $\mathrm{Cr}$ $(90 \%)$. From the leaves, the following percentages were recovered: $\mathrm{Cu}(80 \%), \mathrm{Mn}(108 \%), \mathrm{Zn}(85 \%), \mathrm{Pb}$ (145\%), $\mathrm{Ni}(135 \%)$, and $\mathrm{Cd}(77 \%)$. The Cu contents in the 0-20 cm layer varied from 3.14 to $40.10 \mathrm{mg} \mathrm{kg}^{-1}$ in the cultivated areas (CA) and from undetectable (UD) to $16.07 \mathrm{mg} \mathrm{kg}^{-1}$ in the reference areas (RA). Significant $\mathrm{Cu}$ accumulations $(\mathrm{p}<0.05)$ were found in this layer, with greater contents in the areas after $7,10,11,17$, and 26 years of cultivation (Figure 1 ). In the 9-year-old orchard, a statistically significant difference was also observed but with a higher content in the RA, most likely due to a low number of fertilizer applications on that property. The $\mathrm{Cu}$ levels were highest in the areas under cultivation for 10 and 26 years, with a greater difference from their respective reference areas. This finding indicates that $\mathrm{Cu}$ accumulation is most likely due to the use of fungicides and fertilizers. In general, a trend was observed of greater $\mathrm{Cu}$ contents with increasing orchard age. Analyzing soils under grapes in the same region, Costa (2009) found greater $\mathrm{Cu}$ contents in the vineyards than in Caatinga areas and attributed this increase to the use of agro-chemicals.

For the $20-40 \mathrm{~cm}$ layer, the $\mathrm{Cu}$ content varied from 2.26 to $20.09 \mathrm{mg} \mathrm{kg}^{-1}$ in the orchards and from UD to $9.92 \mathrm{mg} \mathrm{kg}^{-1}$ in the Caatinga. Significant differences were found in the RA after 7, 10, and 26 years. Greater differences were observed in the RA after 6,11 , and 19 years. At this depth, the $\mathrm{Cu}$ content was less affected by agricultural practices.

In relation to the effect of the depth, the results show decreasing $\mathrm{Cu}$ levels with increasing depth in both environments, with greater differences in the areas after $6,7,11,16,17$, and 26 years of cultivation. These decreases were due to the strong interactions of $\mathrm{Cu}$ with soil $\mathrm{OM}$ due to the greater selectivity of the colloid surfaces for the metal (Nascimento \& Fontes, 2004). Other authors also found this decrease with increasing depth, which was attributed to the 
low $\mathrm{Cu}$ mobility, the bonds with the OM through the formation of stable organometallic compounds, and the low solubility of $\mathrm{Cu}$ (Williams et al., 1980; Oliveira \& Matiazzo, 2001; Komárek et al., 2008; Costa, 2009).

The maximum values of $\mathrm{Cu}$ found in this study are below the prevention value $\left(60 \mathrm{mg} \mathrm{kg}^{-1}\right)$ indicated by Brazilian legislation (CONAMA, 2009), which allows the conclusion that the content of this metal in the soils studied would not affect the environmental quality. However, when compared to the values obtained by Biondi et al. (2010) for the state of Pernambuco, specifically in a low rainfall region, the $\mathrm{Cu}$ levels were higher in the $6,11,14$, and 16 year-old orchards than the natural content in Ultisols, both at the surface $\left(3.18 \mathrm{mg} \mathrm{kg}^{-1}\right)$ and in the subsurface $\left(2.90 \mathrm{mg} \mathrm{kg}{ }^{-1}\right)$, indicating $\mathrm{Cu}$ contamination of the soils. The same was observed in the areas after $7,8,9,17$, and 19 years of cultivation when compared to the $\mathrm{Cu}$ content of the
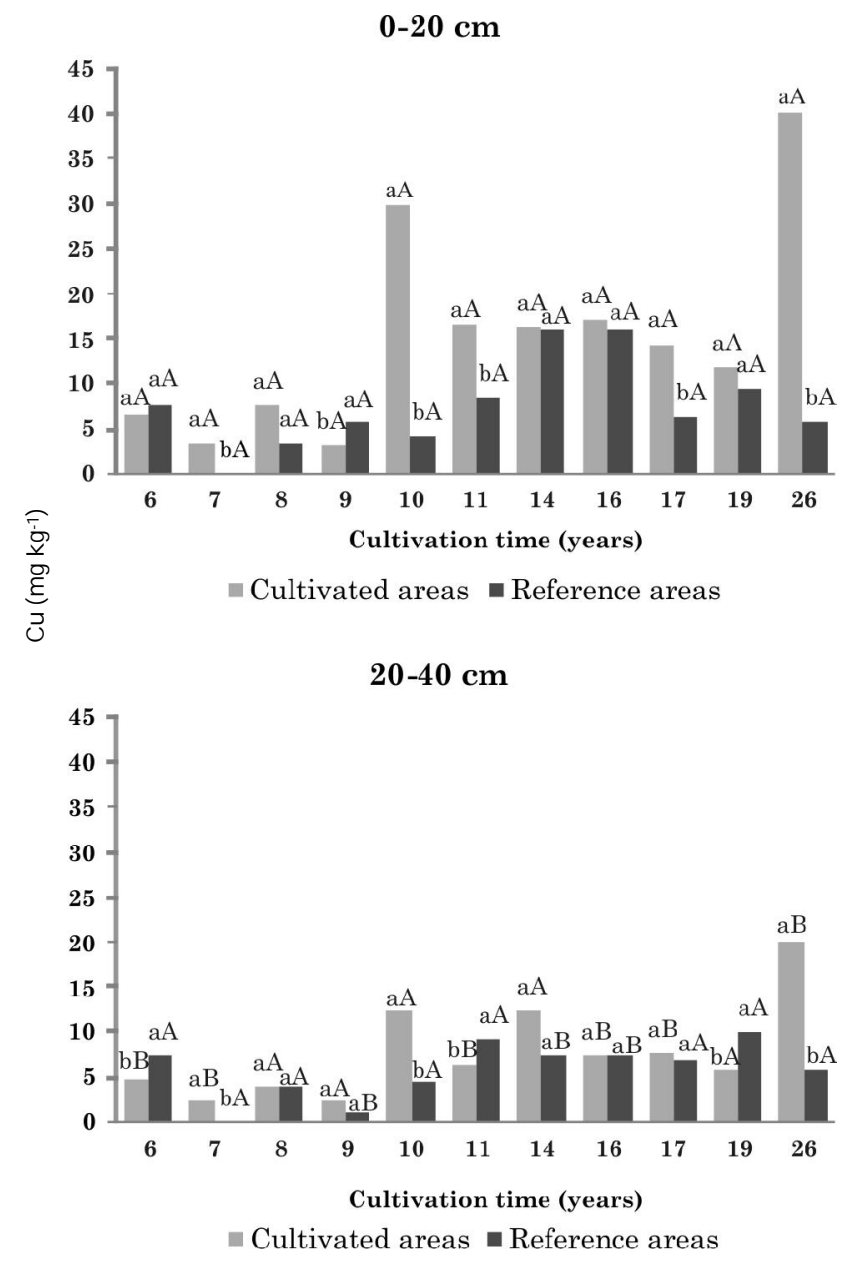

Figure 1. Total $\mathrm{Cu}$ contents in cultivated (CA) and reference areas (RA) in two layers $(0-20$ and 20 $40 \mathrm{~cm}$ ) after different cultivation periods. Means followed by lowercase letters between environments (CA and RA) and capital letters between layers (0-20 and 20-40) did not differ statistically by Tukey's test $(p<0.05)$.
Entisol Quartzipsamments in the surface $(0.50 \mathrm{mg}$ $\left.\mathrm{kg}^{-1}\right)$ and the subsurface $\left(1.28 \mathrm{mg} \mathrm{kg}^{-1}\right)$. In the 10 and 26 year-old orchards, the Cu contents were also higher than the $\mathrm{Cu}$ values found in Oxisols, (surface $\left.2.03 \mathrm{mg} \mathrm{kg}^{-1}\right)$ and in the subsurface $\left(3.40 \mathrm{mg} \mathrm{kg}^{-1}\right)$. Mendes et al. (2010) found a significant increase in the $\mathrm{Cu}$ level in soil under melon, with values as high as 102.5 and $125.33 \mathrm{mg} \mathrm{kg}^{-1}$, above the prevention value of $60 \mathrm{mg} \mathrm{kg}^{-1}$ (CONAMA, 2009).

In the orchards, significant and positive correlations $(\mathrm{p}<0.05)$ were observed between $\mathrm{Cu}$ and $\mathrm{OM}$ and between $\mathrm{Cu}$ and $\mathrm{Zn}$ in the $0-20 \mathrm{~cm}$ layer (Table 1). For $\mathrm{Cu}$ adsorption, organic matter represents one of the main attributes, due to the high degree of selectivity of $\mathrm{OM}$ for the element, with the formation of inner-sphere complexes that result from specific adsorption (Guilherme \& Anderson, 1998). It is worth highlighting that due to the element's ground state electronic configuration [Ar]3d104s1, $\mathrm{Cu}$ is highly reactive with the carboxyl and phenolic groups of OM, resulting in a high binding energy (Croué et al., 2003; Casali et al., 2008). The lack of correlation between $\mathrm{Cu}$ and $\mathrm{P}$ at the surface may be related to the vertical dislocation of $\mathrm{P}$ in organic and inorganic forms caused by the low $\mathrm{P}$ adsorption capacity of these sandy soils (Rheinheimer et al., 2003; Galvão et al., 2008).

In the reference areas, the correlation of $\mathrm{Cu}$ with $\mathrm{Ni}, \mathrm{Pb}, \mathrm{Mn}, \mathrm{Zn}, \mathrm{Cr}$, and $\mathrm{Fe}$ was highly significant and positive $(p<0.01)$, suggesting a common origin of these elements from the source material.

The Ni content in the $0-20 \mathrm{~cm}$ layer varied from UD to $0.65 \mathrm{mg} \mathrm{kg}^{-1}$ in the CA and from UD to 24.67 $\mathrm{mg} \mathrm{kg}^{-1}$ in the RA (Figure 2). Significant differences were found between the CA and RA in this layer after $6,11,14,16,17$, and 19 years, with greater contents in the RA and much lower in the CA. These findings indicate that the agricultural management did not affect Ni accumulation in the orchards. These higher values of $\mathrm{Ni}$ in the RA, mainly than in orchards under cultivation for 14 and 16 years with Ni contents of $24.67 \mathrm{mg} \mathrm{kg}^{-1}$, indicate a strong influence of the source material, while the reduction in the contents of this metal in the orchards in relation to the reference areas may be caused by removal of the crop or by leaching into deeper soil layers.

The higher Ni levels found in the CA are much lower than the prevention value $\left(30 \mathrm{mg} \mathrm{kg}^{-1}\right)$ of CONAMA (2009). In comparison to the quality reference values of Pernambuco (Biondi et al., 2010), the orchards after 11 and 14 years of cultivation have higher Ni contents than the areas in the Sertão region, belonging to the Ultisol class, in the subsurface (1.10 $\mathrm{mg} \mathrm{kg}^{-1}$ ). The high correlation between $\mathrm{Ni}$ and $\mathrm{OM}$, especially in the reference areas, is most likely due to the decrease in soil OM with cultivation (data not shown). This fact was also observed for the other metals studied (Table 1). 
The contents of $\mathrm{Pb}$ in the $0-20 \mathrm{~cm}$ layer varied from UD to $1.32 \mathrm{mg} \mathrm{kg}^{-1}$ in the CA and from UD to $9.29 \mathrm{mg} \mathrm{kg}^{-1}$ in the RA. Significant differences were observed in the surface layer of the orchards after 6 , $11,14,16$, and 19 years of cultivation (Figure 3 ), with higher $\mathrm{Pb}$ contents found in the RA. These results show that $\mathrm{Pb}$ accumulation in the orchard areas was not affected by agricultural practices. In the 20-40 cm layer, the contents of $\mathrm{Pb}$ varied from UD to $3.47 \mathrm{mg} \mathrm{kg}^{-1}$ in the CA and from UD to $7.88 \mathrm{mg}$ $\mathrm{kg}^{-1}$ in the RA. In contrast, Mendes et al. (2010) found higher $\mathrm{Pb}$ concentrations in melon plantations than in the soils with native vegetation. The low values found in the CA may be a result of harvest removal.

The contents of $\mathrm{Mn}$ in the $0-20 \mathrm{~cm}$ layer varied from 45.47 to $133.20 \mathrm{mg} \mathrm{kg}^{-1}$ in the CA and from 15.29 to $348.40 \mathrm{mg} \mathrm{kg}^{-1}$ in the RA. Almost all areas differed significantly, some having greater contents in the CA

Table 1. Linear correlations between heavy metal contents in soil for cultivated (CA) and reference areas (RA) in two layers

\begin{tabular}{|c|c|c|c|c|c|c|c|c|}
\hline & Areas & $\mathbf{C u}$ & $\mathbf{N i}$ & $\mathbf{P b}$ & Mn & $\mathbf{Z n}$ & $\mathrm{Cr}$ & $\mathbf{F e}$ \\
\hline & & & & & $0-20 \mathrm{~cm}$ & & & \\
\hline \multirow[t]{2}{*}{ MO } & $\mathrm{CA}$ & $0.36^{*}$ & $0.37 *$ & $-0.24^{\mathrm{ns}}$ & $0.31^{\mathrm{ns}}$ & $0.33^{\mathrm{ns}}$ & $-0.20^{\mathrm{ns}}$ & $0.17^{\mathrm{ns}}$ \\
\hline & RA & $0.88^{* *}$ & $0.92 * *$ & $0.78^{* *}$ & $0.55^{* *}$ & $0.35^{*}$ & $0.81^{* *}$ & $0.92^{* *}$ \\
\hline \multirow[t]{2}{*}{$\mathrm{P}$} & $\mathrm{CA}$ & $0.22^{\mathrm{ns}}$ & $0.11^{\mathrm{ns}}$ & $-0.11^{\mathrm{ns}}$ & $0.53^{* *}$ & $0.18^{\mathrm{ns}}$ & $0.08^{\mathrm{ns}}$ & $-0.06^{\mathrm{ns}}$ \\
\hline & $\mathrm{RA}$ & $0.05^{\mathrm{ns}}$ & $-0.13^{\mathrm{ns}}$ & $0.17^{\mathrm{ns}}$ & $0.29^{\mathrm{ns}}$ & $0.39 *$ & $-0.16^{\mathrm{ns}}$ & $-0.04^{\mathrm{ns}}$ \\
\hline \multirow[t]{2}{*}{$\mathrm{Cu}$} & $\mathrm{CA}$ & & $0.04^{\mathrm{ns}}$ & $0.02^{\mathrm{ns}}$ & $0.01^{\mathrm{ns}}$ & $0.36^{*}$ & $-0.17^{\mathrm{ns}}$ & $0.33^{\mathrm{ns}}$ \\
\hline & RA & & $0.92^{* *}$ & $0.89^{* *}$ & $0.78^{* *}$ & $0.44^{* *}$ & $0.76^{* *}$ & $0.95^{* *}$ \\
\hline \multirow[t]{2}{*}{$\mathrm{Ni}$} & $\mathrm{CA}$ & & & $0.12^{\mathrm{ns}}$ & $-0.01^{\mathrm{ns}}$ & $-0.18^{\mathrm{ns}}$ & $-0.09^{\mathrm{ns}}$ & $0.43^{*}$ \\
\hline & RA & & & $0.87^{* *}$ & $0.76^{* *}$ & $0.26^{\mathrm{ns}}$ & $0.73^{* *}$ & $0.96^{* *}$ \\
\hline \multirow[t]{2}{*}{$\mathrm{Pb}$} & $\mathrm{CA}$ & & & & $0.01^{\mathrm{ns}}$ & $-0.04^{\mathrm{ns}}$ & $-0.01^{\mathrm{ns}}$ & $0.30^{\mathrm{ns}}$ \\
\hline & $\mathrm{RA}$ & & & & $0.86^{*}$ & $0.26^{\mathrm{ns}}$ & $0.62^{* *}$ & $0.87^{*}$ \\
\hline \multirow[t]{2}{*}{$\mathrm{Mn}$} & $\mathrm{CA}$ & & & & & $0.49^{* *}$ & $-0.22^{\mathrm{ns}}$ & $-0.09^{\mathrm{ns}}$ \\
\hline & RA & & & & & $0.21^{\mathrm{ns}}$ & $0.42^{*}$ & $0.78^{* *}$ \\
\hline \multirow[t]{2}{*}{$\mathrm{Zn}$} & $\mathrm{CA}$ & & & & & & $-0.19^{\mathrm{ns}}$ & $0.06^{\text {ns }}$ \\
\hline & RA & & & & & & $0.21^{\mathrm{ns}}$ & $0.34 *$ \\
\hline \multirow[t]{3}{*}{$\mathrm{Cr}$} & $\mathrm{CA}$ & & & & & & & $0.22^{\mathrm{ns}}$ \\
\hline & RA & & & & & & & $0.77^{* *}$ \\
\hline & & & & & $20-40 \mathrm{~cm}$ & & & \\
\hline \multirow[t]{2}{*}{ MO } & $\mathrm{CA}$ & $0.36^{*}$ & $0.00^{\mathrm{ns}}$ & $-0.00^{\mathrm{ns}}$ & $0.50 * *$ & $0.35^{*}$ & $0.10^{\mathrm{ns}}$ & $-0.02^{\mathrm{ns}}$ \\
\hline & RA & $0.41^{*}$ & $0.92^{* *}$ & $0.69^{* *}$ & $0.56^{* *}$ & $0.50 * *$ & $0.96^{* *}$ & $0.94^{* *}$ \\
\hline \multirow[t]{2}{*}{$\mathrm{P}$} & $\mathrm{CA}$ & $0.48^{* *}$ & $0.18^{\mathrm{ns}}$ & $0.19^{\mathrm{ns}}$ & $0.60^{* *}$ & $0.36^{*}$ & $0.29^{\mathrm{ns}}$ & $0.13^{\text {ns }}$ \\
\hline & RA & $0.31^{\mathrm{ns}}$ & $-0.03^{\mathrm{ns}}$ & $0.33^{\mathrm{ns}}$ & $0.49^{* *}$ & $0.22^{\mathrm{ns}}$ & $-0.11^{\mathrm{ns}}$ & $0.03^{\text {ns }}$ \\
\hline \multirow[t]{2}{*}{$\mathrm{Cu}$} & $\mathrm{CA}$ & & $0.19^{\mathrm{ns}}$ & $0.24^{\mathrm{ns}}$ & $0.11^{\mathrm{ns}}$ & $0.12^{\mathrm{ns}}$ & $-0.09^{\mathrm{ns}}$ & $0.24^{\mathrm{ns}}$ \\
\hline & RA & & $0.54^{* *}$ & $0.74^{* *}$ & $0.76^{* *}$ & $0.73 * *$ & $0.44^{*}$ & $0.60 * *$ \\
\hline \multirow[t]{2}{*}{$\mathrm{Ni}$} & $\mathrm{CA}$ & & & $0.37^{*}$ & $-0.03^{\mathrm{ns}}$ & $-0.19^{\mathrm{ns}}$ & $-0.01^{\mathrm{ns}}$ & $0.73^{* *}$ \\
\hline & RA & & & $0.82 *$ & $0.72^{* *}$ & $0.45^{* *}$ & $0.88^{* *}$ & $0.97 * *$ \\
\hline \multirow[t]{2}{*}{$\mathrm{Pb}$} & $\mathrm{CA}$ & & & & $0.03^{\mathrm{ns}}$ & $-0.14^{\mathrm{ns}}$ & $-0.04^{\mathrm{ns}}$ & $0.18^{\mathrm{ns}}$ \\
\hline & RA & & & & $0.89 * *$ & $0.49 * *$ & $0.68^{* *}$ & $0.78^{* *}$ \\
\hline \multirow[t]{2}{*}{$\mathrm{Mn}$} & $\mathrm{CA}$ & & & & & $0.50 * *$ & $0.11^{\mathrm{ns}}$ & $-0.00^{\mathrm{ns}}$ \\
\hline & RA & & & & & $0.48^{* *}$ & $0.52^{* *}$ & $0.73^{* *}$ \\
\hline \multirow[t]{2}{*}{$\mathrm{Zn}$} & $\mathrm{CA}$ & & & & & & $-0.07^{\mathrm{ns}}$ & $-0.13^{\mathrm{ns}}$ \\
\hline & RA & & & & & & $0.50 * *$ & $0.54^{* *}$ \\
\hline \multirow[t]{2}{*}{$\mathrm{Cr}$} & $\mathrm{CA}$ & & & & & & & $0.25^{\mathrm{ns}}$ \\
\hline & RA & & & & & & & $0.90 * *$ \\
\hline
\end{tabular}

*** and ns: significant at 5 and $1 \%$ by Tukey's test and not significant, respectively 
and others in the RA (Figure 4). The soils contained higher Mn levels in the RA after 6, 11, 14, 16, 17, and 19 years, differing from the areas after $8,9,10$, and 26 years, where the levels were higher in CA than in RA. In the $20-40 \mathrm{~cm}$ layer, the Mn levels varied from 27.53 to $68.27 \mathrm{mg} \mathrm{kg}^{-1}$, and the contents in the RA exceeded those in the CA, in all but the area under cultivation for 8 years, where the CA value was higher than that of the RA. These differences show that in the areas where the Mn levels were lower in the RA than in the CA, a Mn-poor source material had been applied. The other RAs showed that the main Mn sources in soils are the fertilizers, corroborating the data of Micó et al. (2006) and Peris et al. (2008). These low $\mathrm{Mn}$ levels in the CA were expected, given that $\mathrm{Mn}$ is a micronutrient found in large quantities in the mango peel, and after $\mathrm{Fe}, \mathrm{Mn}$ is the most abundant
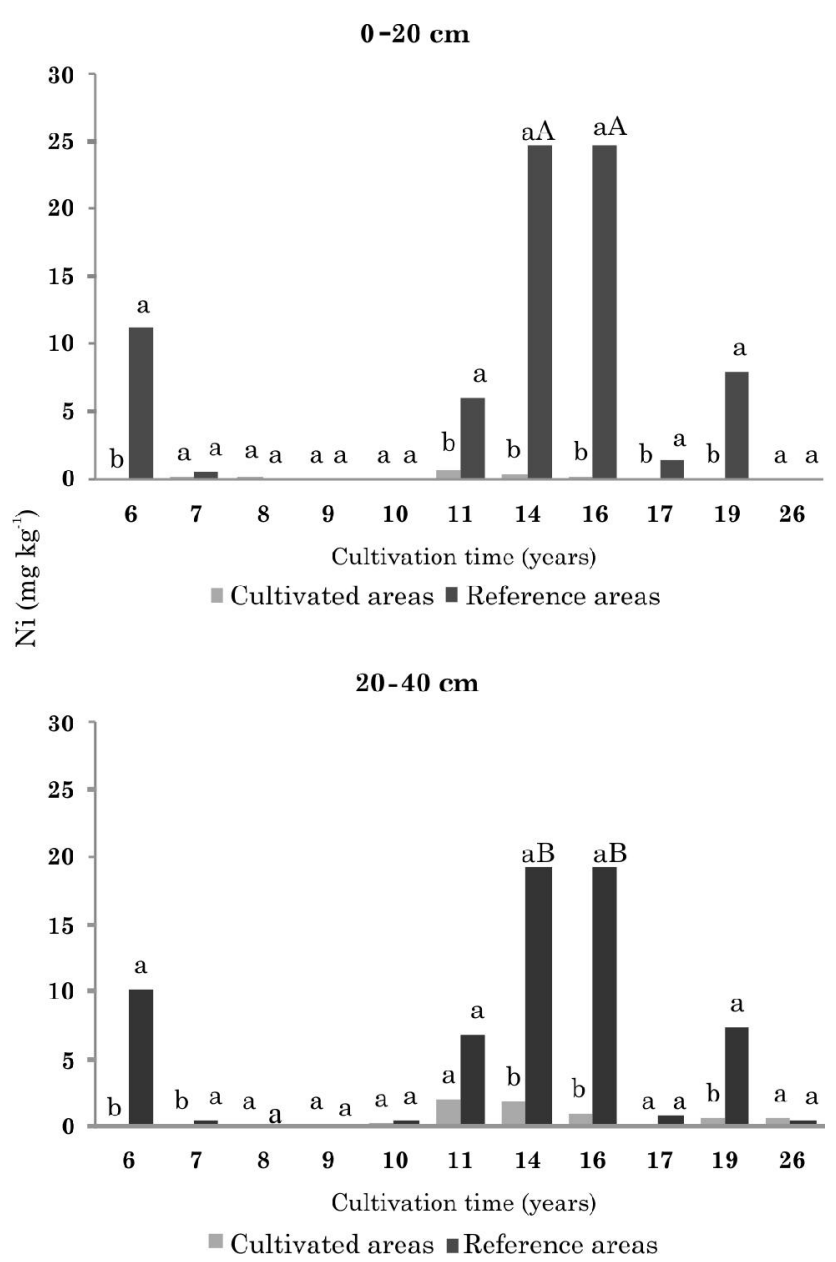

Figure 2. Total Ni contents in cultivated (CA) and reference areas $(\mathrm{RA})$ in two layers $(0-20$ and 20 $40 \mathrm{~cm}$ ) after different cultivation periods. Means followed by lowercase letters between environments (CA and RA) and capital letters between layers (0-20 and 20-40) did not differ statistically by Tukey's test $(p<0.05)$. micronutrient in the fruit pulp (Pinto, 2002). According to Magalhães \& Borges (2000), approximately $2.71 \mathrm{~g}$ of $\mathrm{Mn}$ are exported per ton of fruit. These results show the impoverishment of the studied areas, with a clear need to replace this micronutrient in the soil.

In general, the dynamics of Mn was affected by the content of organic matter, with a decrease in Mn levels observed with increasing soil depth, with the exception of the areas cultivated for 11 and 26 years, where $\mathrm{Mn}$ was accumulated in the deeper layers.

The contents of $\mathrm{Fe}$ in the 0-20 cm layer varied from 1844 to $6491 \mathrm{mg} \mathrm{kg}^{-1}$ in the CA and from 642 to 34,633 $\mathrm{mg} \mathrm{kg}{ }^{-1}$ in the RA. Significant differences were observed for the majority of the areas (Figure 5), with a higher Fe content in the RA, similar to the behavior

\section{0-20 cm}
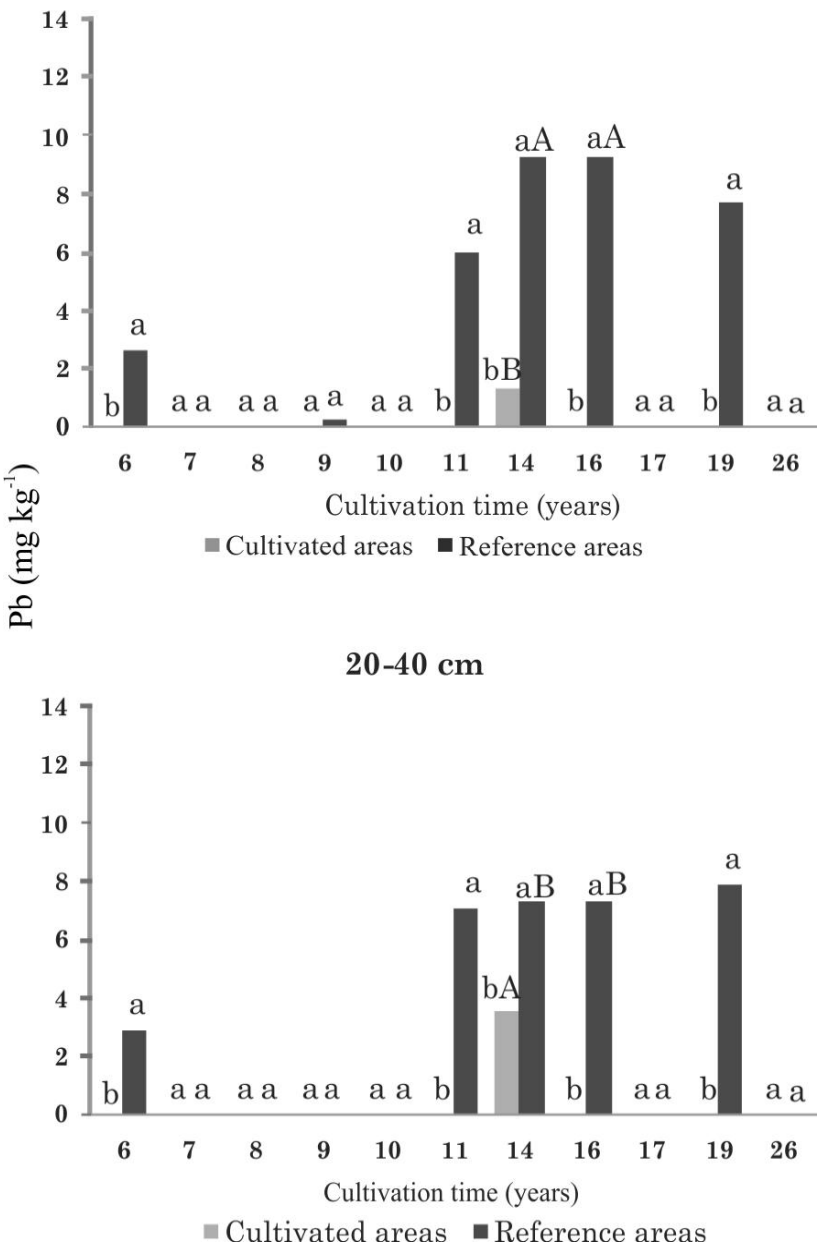

Figure 3. Total $\mathrm{Pb}$ contents in cultivated (CA) and reference areas (RA) in two layers (0-20 and 20$40 \mathrm{~cm}$ ) after different cultivation periods. Means followed by lowercase letters between environments (CA and RA) and capital letters between layers (0-20 and 20-40) did not differ statistically by Tukey's test $(p<0.05)$. 
found for Mn. Only the surface layer of the 7-year-old orchard contained a higher Fe level than that of the RA. In the $20-40 \mathrm{~cm}$ layer, the Fe level varied from $1,479.3$ to $9,361.0 \mathrm{mg} \mathrm{kg}^{-1}$ in the CA and from 758 to $35,000 \mathrm{mg} \mathrm{kg}^{-1}$ in the RA. The Fe levels in the 7 and 9 -year-old orchards were higher than in the RA. The reduction of the $\mathrm{Fe}$ level in the $\mathrm{CA}$ is a result of removal at mango harvest, as $\mathrm{Fe}$ is a micronutrient found at high concentrations in mango fruit (Pinto, 2002; Medeiros et al., 2005).

In the RA, positive and significant correlations were observed between Fe and OM in both layers (Table 1). According to Oliveira \& Nascimento (2006), the contents of available $\mathrm{Fe}$ are linked to the $\mathrm{OM}$ fraction, which explains the high correlations between $\mathrm{Fe}$ and $\mathrm{OM}$ found in this study. This correlation was also

$0-20 \mathrm{~cm}$

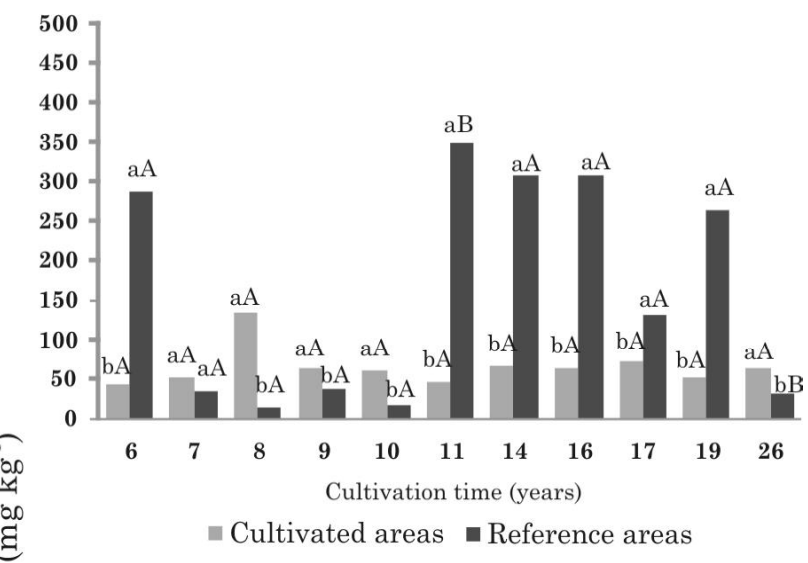

$20-40 \mathrm{~cm}$

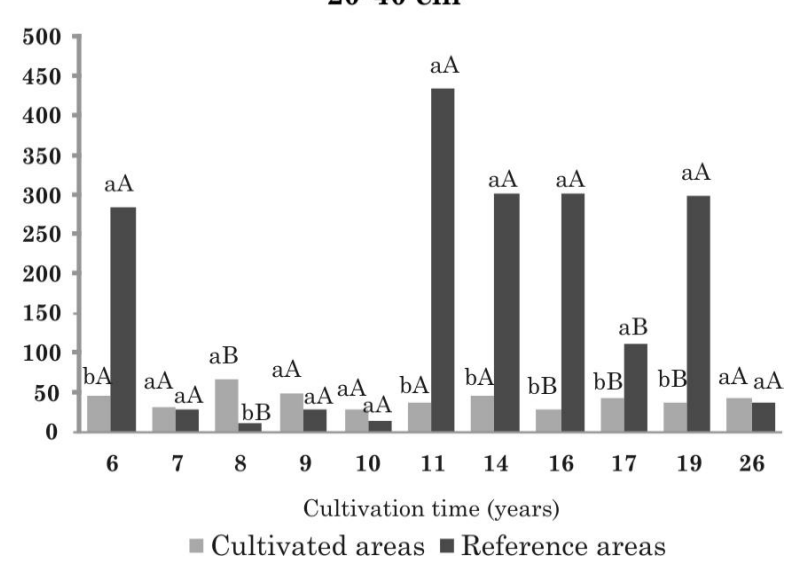

Figure 4. Total contents of Mn in cultivated (CA) and reference areas (RA) in two layers (0-20 and 20$40 \mathrm{~cm}$ ) after different cultivation periods. Means followed by lowercase letters between environments (CA and RA) and capital letters between layers (0-20 and 20-40) did not differ statistically by Tukey's test $(p<0.05)$. reported by Costa (2009) and corroborates the important role of OM for Fe availability.

The $\mathrm{Zn}$ levels in the 0-20 $\mathrm{cm}$ layer varied from 32.07 to $102.87 \mathrm{mg} \mathrm{kg}^{-1}$ in the CA and from 0.20 to $40.53 \mathrm{mg} \mathrm{kg}^{-1}$ in the RA. In the areas after 7, 10, 14, 17,19 , and 26 years, significant differences were found, with greater $\mathrm{Zn}$ contents in the CA (Figure 6), indicating that these areas were affected by alterations caused by $\mathrm{Zn}$ accumulation, most likely due to the use of fertilizers and pesticides. In the $20-40 \mathrm{~cm}$ layer, the $\mathrm{Zn}$ levels varied from 22.40 to $74.20 \mathrm{mg} \mathrm{kg}^{-1}$ in the CA and from 1.73 to $26.20 \mathrm{mg} \mathrm{kg}^{-1}$ in the RA. In most CA, the Zn contents were significantly higher than in the RA. Some companies reported adding zinc sulfate to the fertilizer, as in the 10, 17, 19, and 26year-old orchards, which explains the greater differences in $\mathrm{Zn}$ accumulation in these areas.
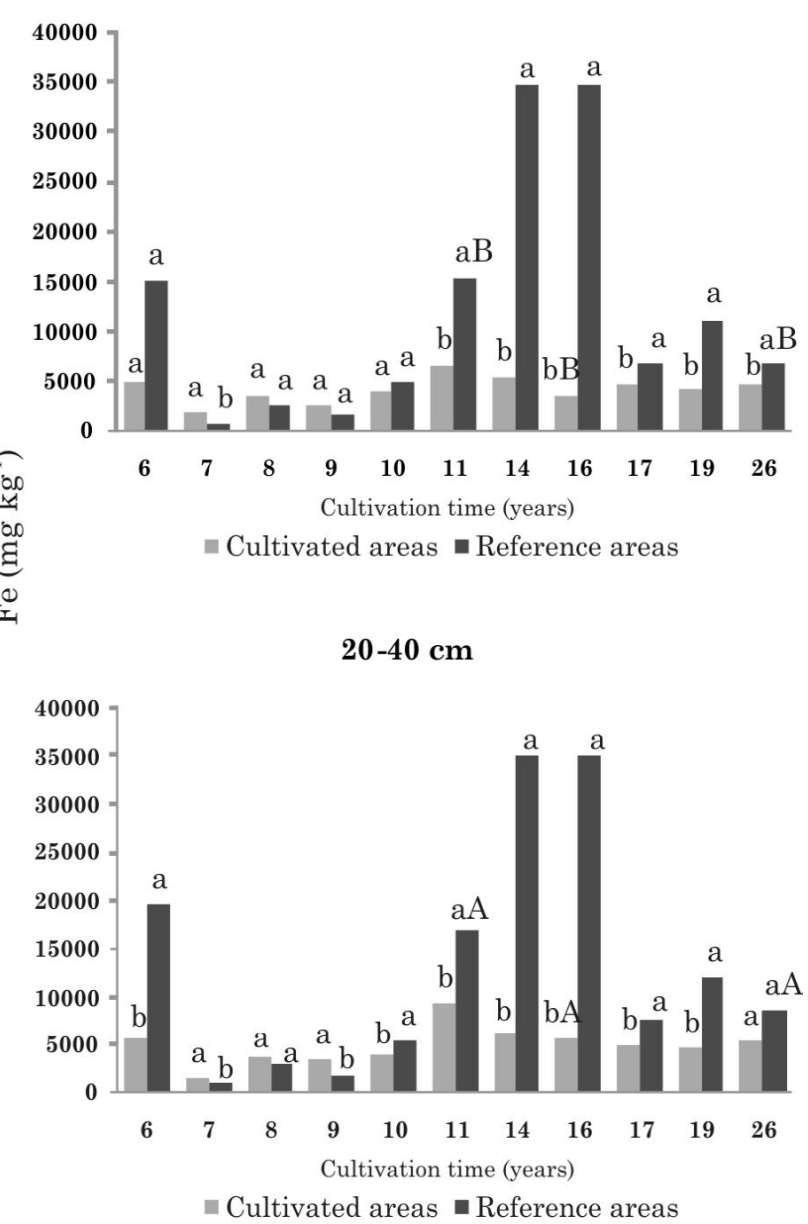

Figure 5. Total contents of Fe in cultivated (CA) and reference areas (RA) in two layers (0-20 and 20$40 \mathrm{~cm}$ ) after different cultivation periods. Means followed by lowercase letters between environments (CA and RA) and capital letters between layers (0-20 and 20-40) did not differ statistically by Tukey's test $(p<0.05)$. 
The $\mathrm{Zn}$ levels in the $20-40 \mathrm{~cm}$ layer presented significant differences between the 10, 17, 19, and 26year-old orchards, with decreasing contents in the deeper soil layers. This dynamic was observed in the RA in relation to the 9-year-old orchard, and the inverse was observed for the 19-year-old orchard, with increasing $\mathrm{Zn}$ concentration with increasing depth. This reduction in the $\mathrm{Zn}$ content from the surface to the subsurface was influenced by changes in the soil $\mathrm{pH}$ caused by liming, as $\mathrm{Zn}$ is a mobile element in acidic soil. However, $\mathrm{Zn}$ is strongly retained by OM and oxides when the $\mathrm{pH}$ increases (Nascimento et al., 2002).

The $\mathrm{Cr}$ levels in the $0-20 \mathrm{~cm}$ layer varied from 6.31 to $77.99 \mathrm{mg} \mathrm{kg}^{-1}$ in the CA and from 0.31 to 68.86 $\mathrm{mg} \mathrm{kg}^{-1}$ in the RA (Figure 7). In the areas after 6, 7, and 8 years, significantly higher Cr levels were observed in the CA than the RA, indicating human influence with fertilizers or pesticides, with greatest effects on the 6-year-old orchard. Significant differences were also observed in the areas after 14 , 16,17 , and 19 years, but with greater $\mathrm{Cr}$ levels in the RA than the CA, showing the influence of the source material on $\mathrm{Cr}$ accumulation. In the $20-40 \mathrm{~cm}$ layer, the $\mathrm{Cr}$ levels varied from 7.23 to $81.03 \mathrm{mg} \mathrm{kg}^{-1}$ in the $\mathrm{CA}$ and from UD to $60.39 \mathrm{mg} \mathrm{kg}^{-1}$ in the RA. At this depth, statistically significant differences were observed, with higher Cr levels in the CA for the same areas at the surface, including the 9-year-old orchard. The 6 year-old orchard was the only area with a $\mathrm{Cr}$ content above the prevention value $\left(75 \mathrm{mg} \mathrm{kg}^{-1}\right)$ indicated by CONAMA (2009), in both layers. These $\mathrm{Cr}$ levels were most likely due to the use of mineral and organic fertilizers. According to Malavolta (2006),

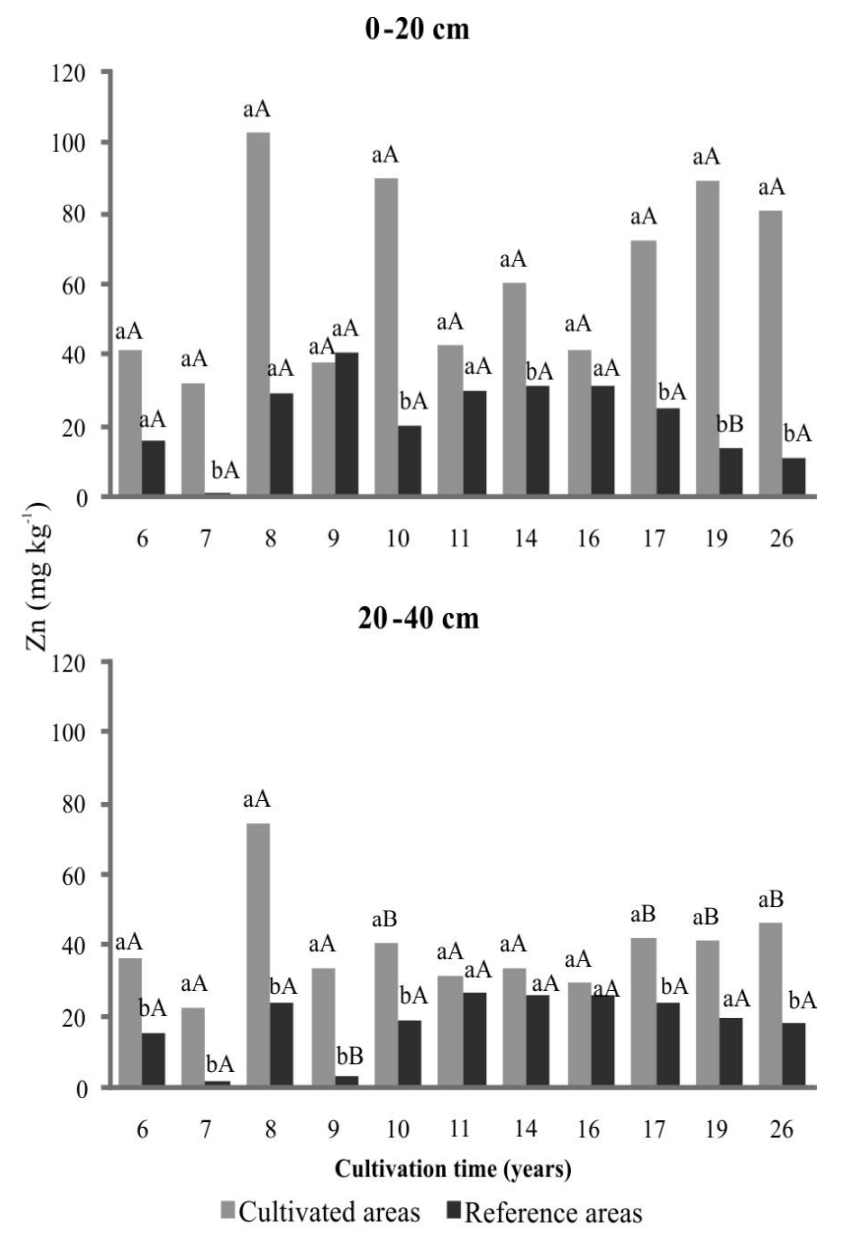

Figure 6. Total $\mathrm{Zn}$ contents in cultivated (CA) and reference areas (RA) in two layers (0-20 and 20$40 \mathrm{~cm}$ ) after different cultivation periods. Means followed by lowercase letters between environments (CA and RA) and capital letters between layers (0-20 and 20-40) did not differ statistically by Tukey's test $(p<0.05)$.

\section{0-20 cm}

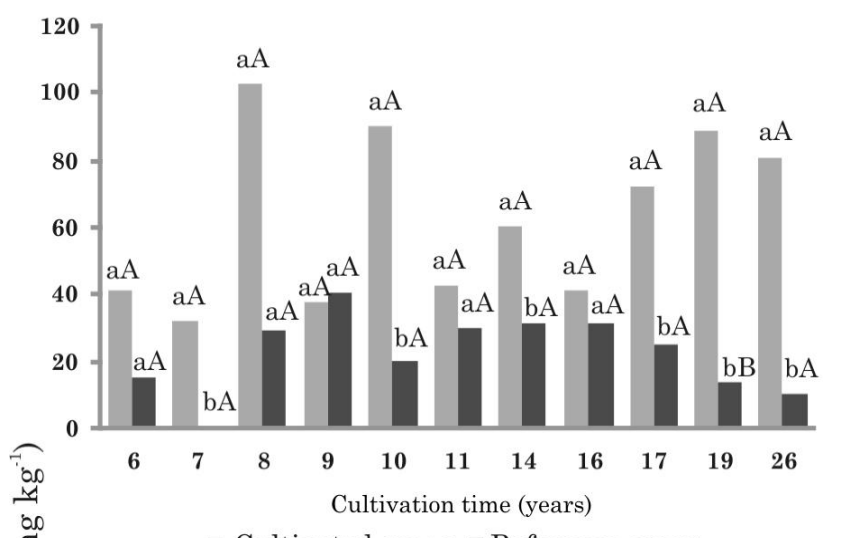

- Cultivated areas $\square$ Reference areas

$20-40 \mathrm{~cm}$

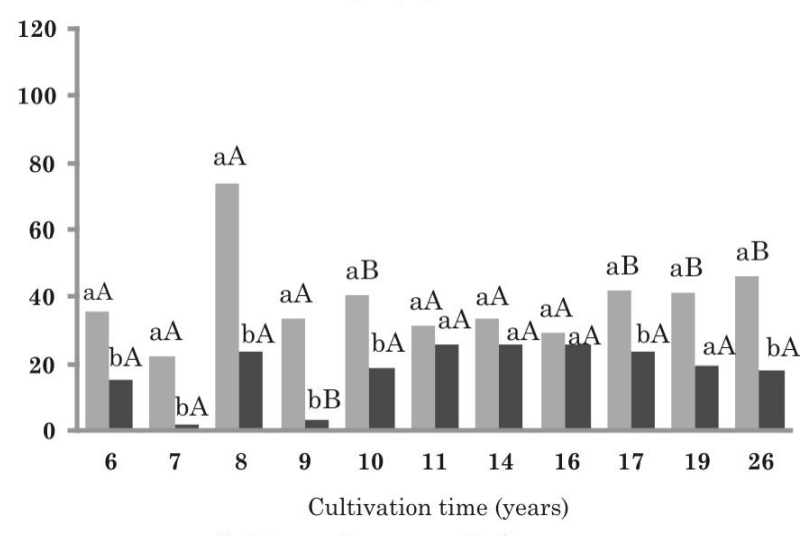

= Cultivated areas - Reference areas

Figure 7. Total Cr levels in cultivated (CA) and reference areas (RA) in two layers (0-20 and 20$40 \mathrm{~cm}$ ) after different cultivation periods. Means followed by lowercase letters between environments (CA and RA) and capital letters between layers (0-20 and 20-40) did not differ statistically by Tukey's test $(p<0.05)$. 
the $\mathrm{Cr}$ level is higher in phosphate fertilizers. These results show that this area needs monitoring, in order to minimize the environmental impact. However, the $\mathrm{Cr}$ levels in all orchards were above the quality reference values of Pernambuco (Biondi, 2010) compared to the respective soil classes of the Sertão region, with the exception of the subsurface layer of the 10-year-old orchard. Thus, Cr contamination was confirmed in the $6,11,14$, and 16-year-old orchards compared with the class of Ultisols (12.60 and 14.70 $\mathrm{mg} \mathrm{kg}^{-1}$ at the surface and subsurface, respectively), in the 7, 8, 9,17, and 19-year-old orchards compared to the Entisol Quartzipsamments (2.38 and $3.95 \mathrm{mg}$ $\mathrm{kg}^{-1}$ in the surface and subsurface, respectively) and in the 10 and 26-year-old orchards compared with the class of Oxisols (10.05 and $11.93 \mathrm{mg} \mathrm{kg}^{-1}$ in the surface and subsurface, respectively).

The $\mathrm{Cu}$ leaf content of the mango trees varied from 4.29 to $63.73 \mathrm{mg} \mathrm{kg}^{-1}$ in the evaluated orchards (Table 2). According to the interpretation ranges of the nutritional status for micronutrients (Quaggio, 1996), the 14-year-old orchard was found to be $\mathrm{Cu}$-deficient. In the areas after 16,17 , and 26 years of cultivation the $\mathrm{Cu}$ levels were between the deficient and adequate range, and the 9-year-old orchard had $\mathrm{Cu}$ contents above the adequate range. The other areas were within the ideal range. A large part of the $\mathrm{Cu}$ found in the leaves was due to the use of $\mathrm{Cu}$-based chemical products for phytosanitary control.

The Ni leaf contents varied from UD to $1.24 \mathrm{mg}$ $\mathrm{kg}^{-1}$ (Table 2). In most areas, the Ni levels were undetectable or close to zero. Only in the 17-year-old orchard the value was higher. Despite considered essential, the Ni demand of mango is very low.

The Mn leaf concentrations varied from 53.87 to $569.60 \mathrm{mg} \mathrm{kg}^{-1}$ (Table 2). Only in the areas after 7 and 19 years of cultivation, the Mn contents were within the range considered adequate (Quaggio, 1996), while in all other orchards the values were clearly higher than the adequate level. Similar results of Mn excess in the mango leaves were also reported by Assis et al. (2004), Rozane et al. (2007), Pinto et al. (2009), and Galli et al. (2009). The high levels may be explained by the high Mn concentration in the soil and by spraying with $\mathrm{Mn}$-based chemical products to control pests and diseases.

The $\mathrm{Zn}$ levels in the leaves varied from 7.76 to $37.71 \mathrm{mg} \mathrm{kg}^{-1}$ (Table 2). The areas after 11, 14, and 16 years of cultivation had $\mathrm{Zn}$ contents below the level considered deficient (Quaggio, 1996). Only in the areas after 19 and 26 years of cultivation, the Mn contents were within the adequate content range. In the other orchards, the $\mathrm{Zn}$ contents varied between deficient and adequate. Pereira et al. (2005) considered Zn to be one of the most important micronutrients for mango. Zn deficiency can cause flower malformation or "Silking" and vegetative malformation or "Witches' Broom", caused by the emission of multiple, small, irregularly shaped, deformed panicles (Silva et al., 2004).

The leaf concentrations of Fe varied from 48.13 to $110.17 \mathrm{mg} \mathrm{kg}^{-1}$ (Table 2). Only in the 9 year-old

Table 2. Heavy metal contents in leaves of mango trees, grown in northeastern Brazil for different cultivation periods

\begin{tabular}{|c|c|c|c|c|c|c|}
\hline Cultivation periods & $\mathbf{C u}$ & $\mathbf{N i}$ & Mn & $\mathbf{Z n}$ & $\mathbf{F e}$ & $\mathbf{C r}$ \\
\hline years & \multicolumn{6}{|c|}{$\mathrm{mg} \mathrm{kg}^{-1}$} \\
\hline 6 & 22.47 & UD & 503.47 & 17.36 & 55.44 & 2.32 \\
\hline 7 & 32.07 & 0.59 & 53.87 & 11.15 & 62.83 & 1.85 \\
\hline 9 & 63.73 & 0.47 & 250.67 & 12.99 & 48.13 & 1.92 \\
\hline 10 & 10.47 & 0.05 & 429.07 & 19.08 & 80.52 & 4.85 \\
\hline 11 & 16.31 & UD & 212.53 & 9.45 & 110.17 & 3.84 \\
\hline 14 & 4.29 & UD & 569.60 & 7.76 & 76.52 & 3.03 \\
\hline 16 & 9.35 & UD & 358.80 & 7.97 & 65.84 & 1.56 \\
\hline 17 & 9.75 & 1.24 & 408.67 & 11.95 & 76.27 & 0.87 \\
\hline 19 & 19.79 & UD & 67.57 & 37.71 & 56.68 & 0.00 \\
\hline \multirow[t]{2}{*}{26} & 8.44 & UD & 135.87 & 25.81 & 60.47 & 0.00 \\
\hline & \multicolumn{6}{|c|}{ Range levels $^{(1)}$} \\
\hline Deficient & $<5$ & * & $<10$ & $<10$ & $<15$ & $*$ \\
\hline Appropriate & $10.0-50.0$ & $*$ & $50.0-100.0$ & $20.0-40.0$ & $50.0-200.0$ & $*$ \\
\hline Excessive & - & $*$ & - & $>100$ & - & $*$ \\
\hline
\end{tabular}

UD: Undetectable; * no content range for these elements; - excessive levels for these elements. ${ }^{(1)}$ Quaggio (1996). 
orchard, the Fe levels were below the adequate range (Quaggio, 1996). All other areas had Fe levels within the adequate range.

The Cr levels in the leaves varied from UD to $4.85 \mathrm{mg} \mathrm{kg}^{-1}$ (Table 2). Only in the 19 and 26 year-old orchards, no $\mathrm{Cr}$ was detected in the mango leaves. There are no reports on the effect of $\mathrm{Cr}$ toxicity on mango trees because the toxic effect of $\mathrm{Cr}$ in plants varies according to its oxidation state $\left(\mathrm{Cr}^{3+}\right.$ or $\left.\mathrm{Cr}^{6+}\right)$ and the tolerance of the species (Castilhos et al., 2001). According to Losi et al. (1994), toxic effects of $\mathrm{Cr}$ are common in most plants when the foliar concentration of the element exceeds $18 \mathrm{mg} \mathrm{kg}^{-1}$.

\section{CONCLUSIONS}

1. The agricultural management practices adopted by the mango-producing companies promoted changes in the heavy metal concentrations of the soils when compared with the soils of the reference areas.

2. In general, the cultivation of mangos caused a surface accumulation of $\mathrm{Cu}$ and $\mathrm{Zn}$ in the soil and a reduction in the contents of $\mathrm{Ni}, \mathrm{Pb}, \mathrm{Mn}$, and $\mathrm{Fe}$ in both the surface and subsurface.

3. Contamination with $\mathrm{Cu}, \mathrm{Zn}$, and $\mathrm{Cr}$ was detected in the mango orchards, indicating the need of monitoring, in order to minimize the environmental impact. For instance, the presence of $\mathrm{Cr}$ in the leaves of the mango trees shows the need to investigate the source of the element.

4. The different management strategies of the different companies led to a deficiency or excess of some metals that are also micronutrients $(\mathrm{Cu}, \mathrm{Zn}$, $\mathrm{Fe}, \mathrm{Mn}$ ) in the evaluated areas. However, the Fe and $\mathrm{Mn}$ levels were adequate for the mineral nutrition of mango in all areas.

\section{ACKNOWLEDGEMENTS}

The authors are grateful to the companies that provided the soil and plant samples used in this study and to Dr. Davi Silva (Embrapa Semi Árido) for helping with soil and plant sampling.

\section{LITERATURE CITED}

ALBUQUERQUE, J.A.S.; MOUCO, M.A.C.; MEDINA, V.D.; SANTOS, C.R. \& TAVARES, S.C.C.H. O cultivo da mangueira irrigada no semi-árido brasileiro. Petrolina, Embrapa Semi-Árido/VALEXPORT, 1999. 77p.

ASSIS, J.S.; SILVA, D.J. \& MORAES, P.L.D. Equilíbrio nutricional e distúrbios fisiológicos em manga 'Tommy Atkins'. R. Bras. Frutic., 26:326-329, 2004.
BERTI, M.J.F. Balanço de uso e aplicação de fertilizantes e agrotóxicos em duas sub-bacias do município de Sorriso MT. In: CONGRESSO BRASILEIRO DE ENGENHARIA SANITÁRIA E AMBIENTAL. 22., Joinville, 2003. Anais... Joinville, 2003. CD ROM.

BIONDI, C.M.; NASCIMENTO, C.W.A.; FABRÍCIO NETA, A.B. \& RIBEIRO, M.R. Teores de Fe, Mn, $\mathrm{Zn}, \mathrm{Cu}, \mathrm{Ni}$ e Co em solos de referência de Pernambuco. R. Bras. CI, Solo, 35:1.057-1.066, 2011.

BIONDI, C.M. Teores naturais de metais pesados nos solos de referência do estado de Pernambuco. Recife, Universidade Federal Rural de Pernambuco, 2010. 58p. (Tese de Doutorado)

CASALI, C.A.; MOTERLE, D.F.; RHEINHEIMER, D.S.; BRUNETTO, G.; CORCINI, A.L.M.; KAMINSKI, J. \& MELO, G.W.B. Formas de dessorção de cobre em solos cultivados com videira na Serra Gaúcha do Rio Grande do Sul. R. Bras. Ci. Solo, 32:1479-1487, 2008.

CASTILHOS, D.D.; COSTA, C.N.; PASSIANOTO, C.C.; LIMA, A.C.R.; LIMA, C.L.R. \& MULLER, V. Adição de cromo hexavalente no crescimento, nodulação e absorção de nutrientes em soja. Ci. Rural, 31:969-972, 2001.

CONSELHO NACIONAL DO MEIO AMBIENTE CONAMA. Resolução $\mathrm{n}^{\circ} 420$, de 28 de dezembro de 2009. "Dispõe sobre critérios e valores orientadores de qualidade do solo quanto à presença de substâncias químicas e estabelece diretrizes para o gerenciamento ambiental de áreas contaminadas por essas substâncias em decorrência de atividades antrópicas.", Diário Oficial [da República Federativa do Brasil], Brasília, DF, no 249, de 30/12/2009. p.81-84. Disponible in: <http:// www.m ma.gov.br/port/con a ma/legiano 1 . cfm? codlegitipo=3\&ano=2009>. Accessed in July 2010 .

COSTA, W.P.L.B. Alterações na fertilidade do solo e teores de metais pesados em solos cultivados com videira. Recife, Universidade Federal Rural de Pernambuco, 2009. 80p. (Tese de Mestrado)

CROUÉ, J.P.; BENEDETTI, M.F.; VIOLlEAU, D. \& LEENHEER, J.A. Characterization and copper binding of humic and nonhumic organic matter isolated from the South Platte River: Evidence for the presence of nitrogenous binding site. Environ. Sci. Technol., 37:328336, 2003.

EMPRESA BRASILEIRA DE PESQUISA AGROPECUÁRIA EMBRAPA. Manga, produção, aspectos técnicos. Brasília, Embrapa Comunicação para Transferência de Tecnologia, 2000. 63p.

GALLI, J.A.; SILVEIRA, L.C.P.; MICHELOTTO, M.D. \& MARTINS, A.L.M. Avaliação da incidência de antracnose, do desempenho e estado nutricional de variedades de mangueira, para cultivo orgânico, na região centro-norte do estado de São Paulo. R. Bras. Frutic., 31:701-709, 2009.

GALVÃO, S.R.S.; SALCEDO, I.H. \& OLIVEIRA, F.F. Acumulação de nutrientes em solos arenosos adubados com esterco bovino. Pesq. Agropec. Bras., 43:99-105, 2008. 
GUILHERME, L.R.G. \& ANDERSON, S.J. Copper sorption kinetics and sorption hysteresis in two oxide-rich soils (Oxisols). In: VENNE, E.A., ed. Adsorption of metals by geomedia: Variables, mechanisms and model applications. San Diego, Academic Press, 1998. p.209-228.

KOMÁREK, M.; SZÁKOVÁ, J.; ROHOŠKOVÁ, M.; JAVORSKÁ, H.; CHRASTNÝ, V. \& BALÍK, J. Copper contamination of vineyard soils from small wine producers: A case study from the Czech Republic. Geoderma, 147:16-22, 2008.

LACERDA, M.A.D. \& LACERDA, R.D.O. Cluster da fruticultura no Pólo Petrolina/Juazeiro. R. Biol. Ci. Terra, 4:1-16, 2004.

LOSI, M.E.; AMRHEIN, C. \& FRANKENBERGER, W.T. Environmental biochemistry of chromium. R. Environ. Contam. Toxicol., 135:91-121, 1994.

LUCAFÓ, B.H.S. \& BOTEON, M. Potencial da manga brasileira no mercado internacional. In: CONGRESSO INTERNACIONAL DE ECONOMIA E GESTÃO DE REDES AGROALIMENTARES, 2., Ribeirão Preto, 2001. Anais... Ribeirão Preto, 2001. CD ROM.

MAGALHÃES, A.F.J. \& BORGRES, A.L. Calagem e adubação. In: MATOS, A.P., org. Manga produção: Aspectos técnicos. Cruz das Almas, Embrapa Mandioca e Fruticultura/ Brasília, Embrapa Comunicação para Transferência de Tecnologia/Frutas do Brasil, 2000. p.63.

MALAVOLTA, E. Manual de nutrição mineral de plantas. São Paulo, Ceres, 2006. 638p.

MEDEIROS, A.A.; AMORIM, J.R.A.; SILVA, D.J.; GUEDES, F.X.; GUERRA, A.G. \& DANTAS, J.A. Composição mineral de folhas e exportação de nutrientes pelos frutos de mangueira, em cultivo irrigado, no Rio Grande do Norte. Natal, EMPARN, 2003. 13p. (Boletim de Pesquisa e Desenvolvimento, 2005)

MENDES, A.M.S.; DUDA, G.P.; NASCIMENTO, C.W.A.; LIMA, J.A.G. \& MEDEIROS, A.D.L. Acúmulo de metais pesados e alterações químicas em Cambissolo cultivado com meloeiro. R. Bras. Eng. Agríc. Amb., 14:791-796, 2010.

MICÓ, C.; RECATALÁ, L.; PERIS, M. \& SÁNCHEZ, J. Assessing heavy metal sources in agricultural soils of an European Mediterranean area by multivariate analysis. Chemosphere, 65:863-872, 2006.

NASCIMENTO, C.W.A.; FONTES, R.L.F.; NEVES, J.C.L. \& MELÍCIO, A.C.F.D. Fracionamento, dessorção e extração química de zinco em Latossolos. R. Bras. Ci. Solo, 26:599606, 2002.

NASCIMENTO, C.W.A. \& FONTES, R.L.F. Correlação entre características de Latossolos e parâmetros de equações de adsorção de cobre e zinco. R. Bras. Ci. Solo, 28:965-971, 2004.

NÚÑEZ, J.E.V.; SOBRINHO, N.M.B.A. \& MAZUR, N. Sistemas de preparo de solo e acúmulo de metais pesados no solo e na cultura do pimentão (Capsicum annum L.). Ci. Rural, $36: 113-119,2006$.

OLIVEIRA, F.C. \& MATTIAZZO, M.E. Mobilidade de metais pesados em um Latossolo Amarelo distrófico tratado com lodo de esgoto e cultivado com cana-de-açúcar. Sci. Agríc., 58:807-812, 2001

OLIVEIRA, A.B. \& NASCIMENTO, C.W.A. Formas de manganês e ferro em solos de referência de Pernambuco. R. Bras. Ci. Solo, 30:99-110, 2006.
OLIVEIRA, T.M.M.; SALVIANO, A.M.; MORAES, M.J.A. \& DUDA, G.P. Disponibilidade de cádmio em diferentes solos do Rio Grande do Norte. R. Caatinga, 21:6-12, 2008.

O'NEILL, P. Environmental chemistry. 2.ed. London, Chapman \& Hall, 1993. 267p.

PERIS, M.; RECATALÁ, L.; MICÓ, C.; SÁNCHEZ, R. \& SÁNCHEZ, J. Increasing the knowledge of heavy metal contents and sources in agricultural soils of the European Mediterranean region. Water Air Soil Poll., 192:25-37, 2008.

PEREIRA, M.E.C.; FONSECA, N. \& SOUZA, F.V.D. Manga: O produtor pergunta, a Embrapa responde. Brasília, Embrapa Informação Tecnológica, 2005.184p.

PINTO, P.A.C. Avaliação do estado nutricional da mangueira Tommy Atkins pelo DRIS e da qualidade pós-colheita de frutos na região do Submédio São Francisco. Viçosa, MG, Universidade Federal de Viçosa, 2002. 124p. (Tese de Doutorado)

PINTO, P.A.C.; DIAS, L.E.; ALVAREZ V., H.V.; CHOUDHURY, M.M. \& VIEIRA, G. Avaliação de estado nutricional da mangueira Tommy Atkins no submédio do vale do rio São Francisco: estabelecimento das normas DRIS. R. Rec. Rurais, 5:5-13, 2009.

QUAGGIO, J.A. Adubação e calagem para mangueira e qualidade dos frutos. In: SÃO JOSÉ, A.R.; SOUZA, I.V.B.; MARTINS FILHO, J. \& MORAIS, O.M., eds. Manga, tecnologia de produção e mercado. Vitória da Conquista, DBZ/UESB, 1996. p.106-135.

RHEINHEIMER, D.S.; ANGHINONI, I.; CONTE, E.; KAMINSKI, J. \& GATIBONI, L.C. Dessorção de fósforo avaliada por extrações sucessivas em amostras de solo provenientes dos sistemas plantio direto e convencional. Ci. Rural, 33:1053-1059, 2003.

RIBEIRO, T.P.; LIMA, M.A.C.; TRINDADE, D.C.G.; SANTOS, A.C.N. \& AMARIZ, A. Uso de revestimentos à base de dextrina na conservação pós-colheita de manga 'Tommy Atkins'. R. Bras. Frutic., 31:343-351, 2009.

ROZANE, D.E.; NATALE, W.; PRADO, R.M. \& BARBOSA, J.C. Amostragem para diagnose do estado nutricional de mangueiras. R. Bras. Frutic., 29:371-376, 2007.

SAS Institute. Statistical analysis system: Procedure guide for personal computer. Cary, 1999.

SILVA, D.J.; PEREIRA, J.R.; MOUCO, M.A.C.; ALBUQUERQUE, J.A.S.; RAIJ, B. van \& SILVA, C.A. Nutrição mineral e adubação da mangueira em condições irrigadas. Petrolina, Embrapa, 2004. (Circular Técnica)

SILVA, D.J. Nutrição e adubação da mangueira em sistema de produção integrada. Petrolina, Embrapa, 2008. (Circular Técnica)

UNITED STATES ENVIRONMENTAL PROTECTION AGENCY - USEPA. Method 3051a - Microwave assisted acid digestion of sediments, sludges, soils, and oils. 1998. Revision 1, Feb. 2007. 30p. Disponible in: <http:// www.epa.gov/epawaste/hazard/testmethods/sw846/pdfs/ 3051a.pdf>. Accessed in February 2010.

WILLIAMS, D.E.; VLAMIS, J.; PUKITE, A.H. \& COREY, J.E. Trace element accumulation, movement, and distribution in the soil profile from massive applications of sewage sludge. Soil Sci., 129:119-132, 1980. 
R. Bras. Ci. Solo, 36:1343-1353 